\title{
IMPACTS OF SEA LEVEL RISE ON ECONOMIC GROWTH IN DEVELOPING ASIA
}

\author{
Ruben Carlo Asuncion and Minsoo Lee
}

NO. 507

January 2017
ADB ECONOMICS WORKING PAPER SERIES 
ADB Economics Working Paper Series

\section{Impacts of Sea Level Rise on Economic Growth in Developing Asia}

Ruben Carlo Asuncion and Minsoo Lee

No. 507 | January 2017
Ruben Carlo Asuncion (rcoasuncion@unionbankph.com) is chief economist in Union Bank of the Philippines and Minsoo Lee (mlee@adb.org) is senior economist in the Economic Research and Regional Cooperation Department of the Asian Development Bank. 
(c) 2017 Asian Development Bank

6 ADB Avenue, Mandaluyong City, 1550 Metro Manila, Philippines

Tel +632 632 4444; Fax +6326362444

www.adb.org

Some rights reserved. Published in 2017.

Printed in the Philippines.

ISSN 2313-6537 (Print), 2313-6545 (e-ISSN)

Publication Stock No. WPS178618-2

DOI: http://dx.doi.org/10.22617/WPS178618-2

Cataloging-In-Publication Data

Asian Development Bank.

Impacts of sea level rise on economic growth in developing Asia.

Mandaluyong City, Philippines: Asian Development Bank, 2017.

1. Climate change. 2. Economic growth. 3. Sea level rise. I. Asian Development Bank.

The views expressed in this publication are those of the authors and do not necessarily reflect the views and policies of the Asian Development Bank (ADB) or its Board of Governors or the governments they represent.

ADB does not guarantee the accuracy of the data included in this publication and accepts no responsibility for any consequence of their use. The mention of specific companies or products of manufacturers does not imply that they are endorsed or recommended by ADB in preference to others of a similar nature that are not mentioned.

By making any designation of or reference to a particular territory or geographic area, or by using the term "country" in this document, $A D B$ does not intend to make any judgments as to the legal or other status of any territory or area.

This work is available under the Creative Commons Attribution 3.0 IGO license (CC BY 3.0 IGO)

https://creativecommons.org/licenses/by/3.0/igo/. By using the content of this publication, you agree to be bound by the terms of this license.

This CC license does not apply to non-ADB copyright materials in this publication. If the material is attributed to another source, please contact the copyright owner or publisher of that source for permission to reproduce it. $A D B$ cannot be held liable for any claims that arise as a result of your use of the material.

Attribution-You should always acknowledge ADB as the source using the following format:

[Author]. [Year of publication]. [Title of the work in italics]. [City of publication]: [Publisher]. (c) ADB. [URL or DOI] [license].

Translations-Any translations you create should carry the following disclaimer:

Originally published by ADB in English under the title [title in italics]. (c) ADB. [URL or DOI] [license]. The quality of the translation and its coherence with the original text is the sole responsibility of the translator. The English original of this work is the only official version.

Adaptations-Any adaptations you create should carry the following disclaimer:

This is an adaptation of an original work titled [title in italics]. (c) ADB. [URL or DOI][license]. The views expressed here are those of the authors and do not necessarily reflect the views and policies of ADB or its Board of Governors or the governments they represent. ADB does not endorse this work or guarantee the accuracy of the data included in this publication and accepts no responsibility for any consequence of their use.

Please contact pubsmarketing@adb.org if you have questions or comments with respect to content, or if you wish to obtain copyright permission for your intended use that does not fall within these terms, or for permission to use the ADB logo.

Notes:

1. In this publication, " $\$$ " refers to US dollars.

2. Corrigenda to ADB publications may be found at http://www.adb.org/publications/corrigenda 


\section{CONTENTS}

TABLES AND FIGURES

ABSTRACT

$\begin{array}{ll}\text { I. INTRODUCTION } & 1\end{array}$

II. THE IMPACTS OF SEA LEVEL RISE

$\begin{array}{llr}\text { A. Economic Growth } & 4 \\ \text { B. Migration } & 5 \\ \text { C. Tourism } & 7\end{array}$

III. SEA LEVEL RISE ADAPTATION STRATEGIES $\quad 7$

A. $\quad$ Retreat 8

B Accommodation 8

C. Protection 8

IV. POLICY RECOMMENDATIONS

V. CONCLUSIONS

$\begin{array}{ll}\text { REFERENCES } & 13\end{array}$ 


\section{TABLES AND FIGURES}

\section{TABLES}

1 Summary of Sea Level Rise Impact Estimates on Global Economic Growth

$2 \quad$ Migration Impact Estimates on Developing Asia

3 Sea Level Rise Impact Estimates on Selected Countries in Developing Asia and the Pacific

\section{FIGURES}

1 Global Average Absolute Sea Level Change, 1880-2014

$2 \quad$ Mean Sea Level Trends in Developing Asia 


\begin{abstract}
Global sea level rise (SLR) variations have undeniably begun to make an impact on highly vulnerable economies. These impacts of SLR are a key component of the projected economic damage of climate change, an important input to climate change policies and adaptive measures. This paper considers SLR projections and its impact on the economy and includes a consolidation of various related studies. Estimated global gross domestic product (GDP) loss by 2100 ranges from $0.3 \%$ to as high as of $9.3 \%$ (Hinkel et al. 2014; Pycroft, Abrell, and Ciscar 2015). Climate change impact should be addressed at the global level through a locally focused effort where education and acceptance by all stakeholders are crucial and warranted. Further, this paper tackles several adaptive strategies as a response to SLR which include retreat, accommodation, and protection. The retreat strategy simulates that SLR causes the loss of inundated land and incurs planned relocation (migration) costs above a certain sea level. The accommodation strategy allows usage of vulnerable areas or land and limits damage by floodproofing or raising structures. Finally, the protection strategy projects that land will be protected from SLR damage by sea walls or other barriers of a certain height. On the other hand, Diaz (2016) estimates a median adaptation cost from migration at $16 \%$ of GDP under the least-cost strategy by 2050 . In general, the education of and the acceptance by the concerned local community will be crucial in the successful implementation of SLR adaptation strategies, notwithstanding parallel mitigation efforts on a global scale.
\end{abstract}

Keywords: climate change, economic growth, sea level rise

JEL codes: Q50, Q54 


\section{INTRODUCTION}

The global sea level during the past few million years' ice age cycles has been varying by more than 100 meters (m).' Over the last century, however, sea levels have been rising much faster than in other previous millennia. The National Aeronautics and Space Administration reported that February 2016 had the highest increase in sea height variation at 74.8 millimeters $(\mathrm{mm})$ since 1993 and the global mean sea level change is at $3.4 \mathrm{~mm}$ per year. ${ }^{2}$ Figure 1 shows the historical global average absolute sea level change. ${ }^{3}$

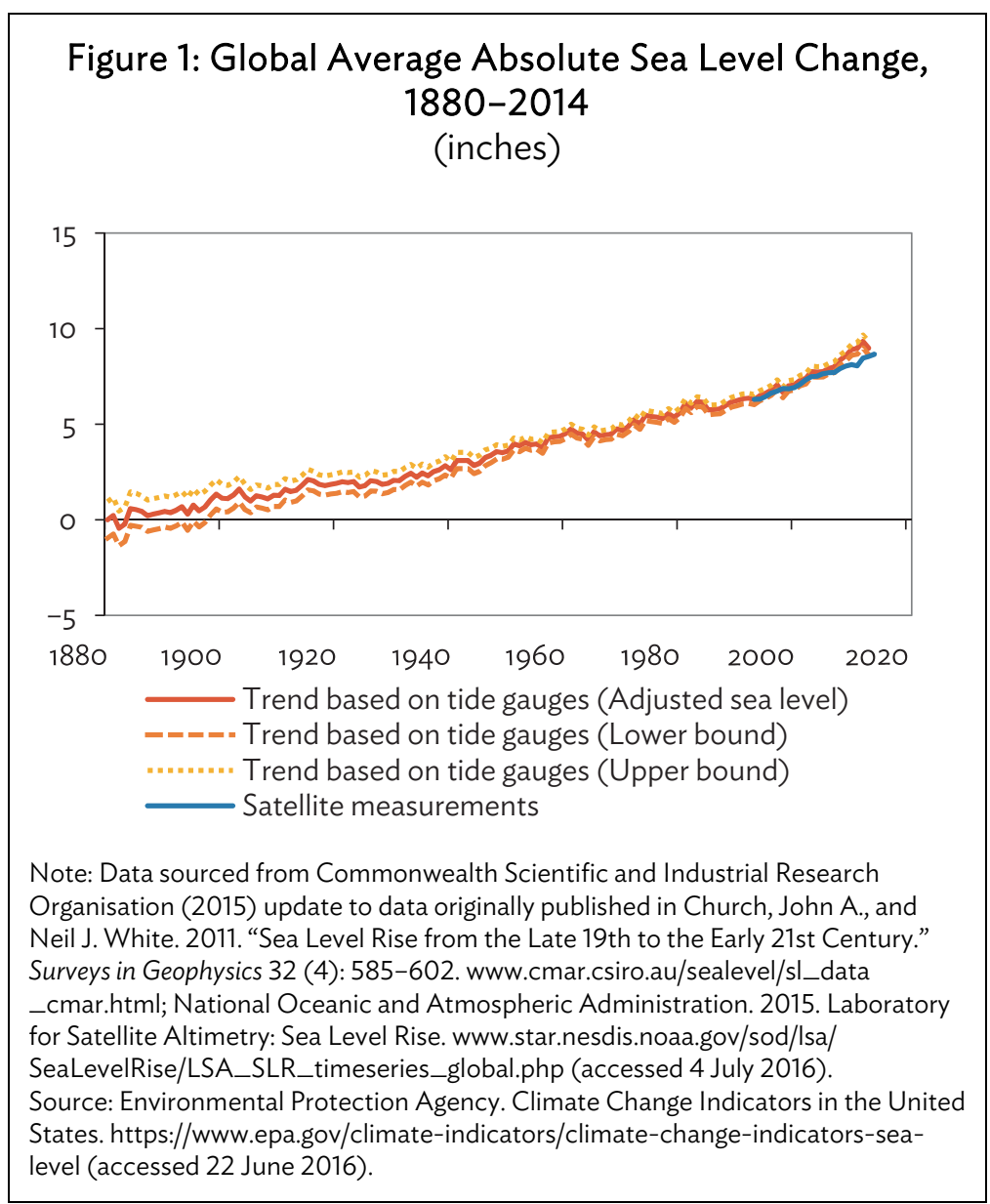

Church and White (2011) estimate that the rise in global average sea level from satellite altimeter data is about $0.2 \mathrm{~m}$ from 1993 to 2009. Schaeffer et al. (2012) use a semi-empirical model, calibrated with sea level data of the past 100 years, and the resulting estimate is about $0.25 \mathrm{~m}$ lower with an unmitigated emissions scenario, but $0.15 \mathrm{~m}$ above a hypothetical scenario reducing global emissions to zero by 2016. The Intergovernmental Panel on Climate Change (IPCC) 2013 estimated that average global sea levels have increased by around $3 \mathrm{~mm}$ annually since the early 1990s and are expected to further increase from $0.75 \mathrm{~m}$ to $1.90 \mathrm{~m}$ during $1990-2100$ as temperatures continue to

1 According to IPCC (2007), the global sea level rose by about 120 m during the several millennia that followed the end of the last ice age (approximately 21,000 years ago) and stabilized between 3,000 and 2,000 years ago.

2 National Aeronautics and Space Administration. https://www.nasa.gov/ (accessed July 2016).

3 Environmental Protection Agency estimates the cumulative changes in sea level for the world's oceans, based on a combination of long-term tide gauge measurements and recent satellite measurements. 
rise. Recent literature (Kopp et al. 2014) projects 20th century global mean sea level estimates at 0.3$1.2 \mathrm{~m}$ using the different Representative Concentration Pathways (RCPs) scenarios. On the other hand, Mengel et al. (2016) recognize that the accelerating sea level rise (SLR) is mainly due to anthropogenic climate change and project an anthropogenic SLR of $0.28-1.31 \mathrm{~m}$ in 2100 for the different concentration scenarios.

SLR is caused by the ongoing global climate change such as thermal expansion of ocean waters and melting of land-ice due to higher ambient temperatures. Several studies confirm that increased air temperatures cause thermal expansion of oceans as they absorb $85 \%$ of the excess heat trapped by the atmosphere and were the main driver of global SLR for 75-100 years after the start of the industrialization (Cazenave and Llovel 2010; Levitus et al. 2009; Levitus, Antonov, and Boyer 2005; Levitus et al. 2001). Vermeer and Rahmstorf (2009) also find a significant relationship between sea level and temperature over the period 1800-2000. Another significant factor that affects global SLR is the faster shrinking of land ice-glaciers, ice caps, and ice sheets-due to higher temperature (Cazenave and Llovel 2010; Lombard et al. 2005). The rise in sea level is accelerating both globally and regionally in many places.

Figure 2 illustrates mean sea level trends of the People's Republic of China (PRC), India, Japan, Kiribati, the Philippines, and Singapore. Davao in the Philippines has the highest mean sea level trend at 5.32 millimeters per year $(\mathrm{mm} / \mathrm{yr}$ ) with a $95 \%$ confidence interval of $+/-1.30 \mathrm{~mm} / \mathrm{yr}$ based on monthly mean sea level data from 1948 to 2008, which is equivalent to a change of $0.5 \mathrm{~m}$ in 100 years. This is followed by Nagasaki in Japan at $2.2 \mathrm{~mm} / \mathrm{yr}$ and Singapore at $1.53 \mathrm{~mm} / \mathrm{yr}$. Moreover, Strassburg et al. (2015) noted that Southeast Asia has one of the highest sea level trends observed by modern satellites and the long-term sea level trends will continue to be affected by global mean sea level rise occurring now and in the future.

Rapid SLR (more than $1 \mathrm{~m}$ per century) is adversely affecting the environment, especially the coastal areas. Coastal areas have been used extensively and will continue to increase through the 21st century (IPCC 2007), as various settlements were developed due to access for food and livelihood. ${ }^{4}$ Ciscar et al. (2012) highlighted that, among the most important sectors affected by climate change (such as agriculture, river floods, coastal systems, and tourism), coastal systems are the most negatively affected in all European regions due to increasing sea levels. In fact, Diaz (2016) stressed that coastal sector impacts from SLR are an important component of projected economic damage of climate change. Hauer et al. (2016) found that almost 13 million people may be living in vulnerable regions along coasts in the United States by 2100 if sea levels rise by $1.8 \mathrm{~m}$. Moreover, the most vulnerable to SLR are mostly small island states and atoll countries. An example close to the highlighted and anticipated impact of SLR are: one is Kiribati, an island in the Pacific, and another is the city-state of Singapore, where notably, the impact of SLR is slowly being felt in market and nonmarket areas.

According to the World Bank (2013), Kiribati is one of the world's most vulnerable countries to climate change and extreme weather. Kiribati is one of the first Pacific islands that will be in danger of becoming uninhabitable due to climate change (Decloitre 2010). Kiribati is composed of coral atolls and reef islands scattered across a swath of the Pacific Ocean and lies no higher than $1.83 \mathrm{~m}$ above sea

4 The Fourth IPCC Assessment Report (IPCC 2007) estimated that $23 \%$ of the world's population, or around 10 million people, live within 100 kilometers' distance of the coast. Based on the World Resources report, 39\% of the world's population, or 2.2 billion people, lived on or within 100 kilometers of a seashore (UNDP et al. 2000). Recent studies reveal that up to 600 million people live in low elevation coastal zones and 200 million people live within coastal floodplains. 
level. With Kiribati's geographical situation, rising seas and intensifying storms are threats not only to the people but also to their livelihoods, according to government's report to the United Nations. A study conducted by the World Bank (2013) reports that Tarawa, the capital of Kiribati, under the climate change scenarios could experience annual damages of about $\$ 8$ million- $\$ 16$ million. Moreover, inundation and storm surges can affect Tarawa's coast through shoreline displacement resulting from the rise in sea level (by 0.2-0.4 meters by 2050). Further, SLR can disrupt socioeconomic activities in Kiribati such as an increase in causeways destroyed, damaged coral reefs, and shoreline erosion. Thus, migration of communities is expected as land will be lost and freshwater supplies become critical. In fact, it has been reported that the Government of Kiribati has encouraged residents to consider moving abroad with job skills necessary to be employed (New York Times 2016).

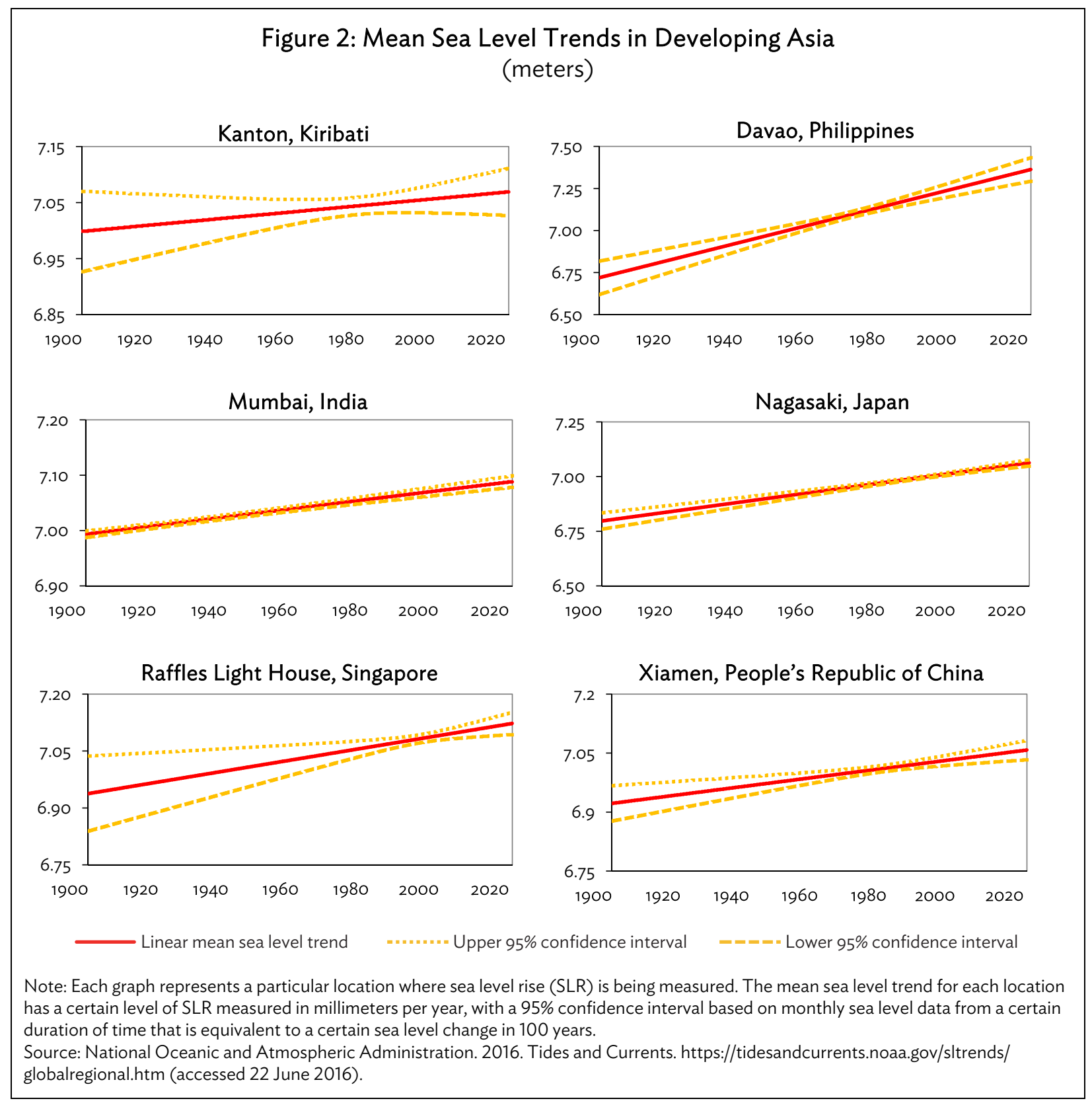


Another small low-lying island-state that is worth noting is Singapore. The rise in sea level poses threats to Singapore as it lies only 15 meters $(\mathrm{m})$ above the mean sea level, with about $30 \%$ of the island at less than $5 \mathrm{~m}$ above the mean sea level, according to Singapore's National Climate Change Secretariat (NCCS). Navaratnarajah (2015) relates SLR to increases of carbon emissions and temperature and notes that warming can cause Singapore's sea level to increase by $9.5 \mathrm{~m}$, leaving 745,000 Singaporeans' homes submerged. Moreover, Ng and Mendelsohn (2005) examine the impact of SLR in Singapore and explore whether Singapore should defend its coast or allow it to be inundated. Based on their study, the annual cost of protecting Singapore's coasts is estimated to rise over time as the sea level rises and will range from $\$ 0.3$ million- $\$ 5.7$ million by 2050 to $\$ 0.9$ million$\$ 16.8$ million by 2100 . Depending on the SLR simulation, the present value of these costs ranges from $\$ 0.17$ million to $\$ 3.08$ million. Clearly, the regions or countries most vulnerable to SLR include atoll countries and small islands states like Kiribati and Singapore. Hence, there is a need for relevant discussions and consensus on how SLR will be dealt with through adaptation or mitigation.

Global SLR threatens not only the coastal communities as development continues but also national economies. The consequences of SLR can also lead to reduced growth and out-migration. As the sea level rises, there will be threats to food and water security, infrastructure, and public health and safety. Agricultural lands and traditional water sources will be compromised, bringing uncertainty of food and potable water sources. Infrastructure such as roads, bridges, and railways will also be exposed as the sea level rises. According to the Food and Agriculture Organization of the United Nations (2014), fisheries and aquaculture provide livelihoods to $10 \%-12 \%$ of the world's population which means that healthy oceans represent jobs, food, and protection. This mounting pressure on existing links of people to economic resources will definitely have corresponding negative impacts on socioeconomic activities and consequently growth in the long run. Furthermore, low-lying and coastal areas will frequently experience more flooding which may threaten the existing public health infrastructure and the general safety of citizens, thus leading to human migration to high islands and continental sites. This paper surveys the potential impacts of SLR to economic growth, tourism, and migration, as well as the probable scenarios of SLR on economic activities for policy making and poverty alleviation in the long run. Moreover, it explores the various adaptive measures and the underlying cost to consider to combat SLR, especially for vulnerable countries, and their implications.

Section II focuses on and summarizes the effects of SLR on economic growth and various economic activities including the effect on tourism and migration. Climate change adaptation due to SLR is highlighted in section III, including the strategies that are important to consider. Sections IV and $\checkmark$ present policy recommendations and conclusions, respectively.

\section{THE IMPACTS OF SEA LEVEL RISE}

\section{A. Economic Growth}

The growing evidence of the enormous global impact of rising temperatures on society warrants investigation into the magnitude of such climate impact on economic activities. ${ }^{5}$ As the temperature increases, the global sea level rises as well. This firmly confirms the need to delve into the effects of SLR on economic activities, losses, and development in general. Hallegate (2012) reveals that SLR

5 Dell, Jones, and Olken (2012) and Burke, Hsiang, and Miguel (2015) are few of the studies that investigate and estimate the impact of rising temperature to the economy. 
largely affects economic growth and welfare at least on the regional scale and channels through the following: (i) the loss of land, (ii) the loss of infrastructure and physical capital, (iii) the loss of social capital and the additional cost from extreme events and coastal floods, and (iv) an increase in expenditure for coastal protection. Further, Hallegate (2012) notes that SLR is a progressive and dynamic process and that it requires a continuous adaptation process in order to cope or readily react to it. Moreover, the complexity of SLR and how it can affect economic growth clearly pose a challenge for quantitative analysis in terms of measurement and actuality. The existing literature on the economic impacts of SLR borders on the investigation of its global and local "coastal effects," i.e., countries along the coasts are most economically and environmentally vulnerable and challenged.

Table 1 describes two recent SLR studies that deal with measuring its economic impact as a percentage of gross domestic product (GDP) under different scenarios and models used. Using sea level modeling techniques, SLR projections ranged from a low of $0.35 \mathrm{~m}$ under the RCP 2.6 scenario to as high as $1.75 \mathrm{~m}$ in 2100 . The global impact estimate on GDP by SLR is, on average, from $0.15 \%$ to as much as $9.3 \%$ of global GDP. Pycroft, Abrell, and Ciscar (2015) even project global GDP loss of 0.5\% under the highest SLR scenario, ${ }^{6}$ with a loss of welfare (measured in equivalent variation) at $1.91 \%$ worldwide by 2100 , which is equivalent to $\$ 2.82$ trillion by $2100 .{ }^{7}$

\section{Table 1: Summary of Sea Level Rise Impact Estimates on Global Economic Growth}

\begin{tabular}{|c|c|c|c|c|c|}
\hline Author(s) and Title of Paper & $\begin{array}{c}\text { Year } \\
\text { Published }\end{array}$ & Period & $\begin{array}{c}\text { Climate } \\
\text { Scenarios }\end{array}$ & $\begin{array}{l}\text { Sea Level } \\
\text { Projections } \\
\text { (meters) }\end{array}$ & $\begin{array}{c}\text { Damage } \\
\text { Cost } \\
\text { (\% of GDP) }\end{array}$ \\
\hline \multirow{2}{*}{$\begin{array}{l}\text { Hinkel et al. } \\
\text { Coastal Flood Damage and } \\
\text { Adaptation Cost under 21st } \\
\text { Century Sea Level Rise }\end{array}$} & \multirow[t]{2}{*}{2014} & \multirow[t]{2}{*}{$2000-2100$} & RCP 2.6 & 0.35 & $0.3-0.5$ \\
\hline & & & RCP 8.5 & 0.74 & $1.2-9.3$ \\
\hline \multirow{3}{*}{$\begin{array}{l}\text { Pycroft, Abrell, and Ciscar } \\
\text { The Global Impacts of Extreme Sea } \\
\text { Level Rise: A Comprehensive } \\
\text { Economic Assessment }\end{array}$} & \multirow[t]{3}{*}{2015} & \multirow[t]{3}{*}{$2010-2100$} & A1B & 0.5 & 0.15 \\
\hline & & & RAHM & 1.12 & 0.33 \\
\hline & & & High & 1.75 & 0.5 \\
\hline
\end{tabular}

GDP = gross domestic product.

Notes: A1B is consistent with the A1B IMAGE scenario, which assumes a warming of $2.4^{\circ} \mathrm{C}$ by the 2050 s and $3.8^{\circ} \mathrm{C}$ by the 2090 s. RAHM is from Rahmstorf (2007), where the sea level rises by 1.4 meters by 2100 . RCP are the Representative Concentration Pathways. High is from Lowe and Gregory (2010), where the sea level rise is projected to be 2 meters by 2100.

Sources: Jochen Hinkel, Daniel Lincke, Athanasios T. Vafeidis, Mahé Perrette, Robert James Nicholls, Richard S. J. Tol, Ben Marzeion, Xavier Fettweis, Cezar lonescu, and Anders Levermann, 2014. "Coastal Flood Damage and Adaptation Costs under 21st Century Sea Level Rise." Proceedings of the National Academy of Sciences of the United States of America 111(9): 3292-3297. Jonathan Pycroft, Jan Abrell, and JuanCarlos Ciscar. 2015. "The Global Impacts of Extreme Sea Level Rise: A Comprehensive Economic Assessment." Environmental Resource Economics. doi: 10.1007/s10640-014-9866-9

\section{B. Migration}

SLR is expected to bring significant changes in migration patterns in vulnerable areas. Future SLR is projected to reach $0.9 \mathrm{~m}$ by 2100 (IPCC 2001) to as high as $1.75 \mathrm{~m}$ under the high sea-level scenario in the 21st century (Pycroft, Abrell, and Ciscar 2015). According to Perch-Nielsen (2004), the impact of SLR would increase flood frequency, erosion, inundation, and rising water tables to vulnerable communities, creating risk to food security and livelihood of the population. However, Raleigh, Jordan, and Salehyan (2008) stress that international migration might be quite limited since less developed

6 According to Lowe and Gregory (2010), the sea level will increase by $2 \mathrm{~m}$ by 2100.

7 Using the Diaz (2016) global GDP estimate of \$147.6 trillion under RCP 8.5. 
countries lack abilities to mitigate climate change and instead try to incorporate physical and social hazards into their livelihoods as their coping mechanism (Mula 1999; Maxwell 1999; Meze-Hausken 2000; Findley 1994).

Pycroft, Abrell, and Ciscar (2015) estimate the impact of migration on GDP and find that the PRC, the Republic of Korea, and Indonesia have the highest estimated total impact among the region at a combined $\$ 6$ billion, or almost $10 \%$ of the world's estimates under the high scenario by 2080 (Table 2). Ericson et al. (2006) estimate that there are around 8.7 million people expected to be displaced by 2050 due to rising sea levels. ADB (2013) also reaches a similar conclusion, stating that $S L R$ is projected to significantly impact the Pacific region, damaging infrastructure and human habitats. The ADB results are based on the IPCC Special Report on Emissions Scenarios and are interpreted as percentage deviations from a baseline situation without projected changes in climate conditions. The two integrated assessment models-Framework for Uncertainty, Negotiation and Distribution 3.6 (FUND3.6) and Policy Analysis of the Greenhouse Effect 09 (PAGE09) - estimate the total costs of climate change as a percentage of GDP increase every year. ${ }^{8}$ Estimates from FUND3.6 indicate that costs range between $2.7 \%$ and $3.5 \%$ of annual GDP equivalent in 2050 and increase to $4.6 \%-10.9 \%$ by 2100. PAGE09 provides lower estimates of economic costs ranging between $2.2 \%$ and $2.8 \%$ of annual GDP equivalent in 2050 and higher estimates by 2100 ranging between $2.9 \%$ and $12.7 \%$ depending on the emissions scenarios. ADB (2013) finds that, regardless of which model is used, the results suggest the Pacific will be greatly affected by climate change by 2050 and losses are projected to rise over time under all scenarios, and would be largest with high emissions scenarios.

Table 2: Migration Impact Estimates on Developing Asia

(\$ billion)

\begin{tabular}{l|c|c|c}
\hline Region/Country & A1B & RAHM & High \\
\hline People's Republic of China & 5.7 & 4.5 & 4.5 \\
\hline Republic of Korea & 0.0 & 3.8 & 1.0 \\
\hline Indonesia & 0.1 & 0.6 & 0.5 \\
\hline India & 0.7 & 0.5 & 0.6 \\
\hline Rest of South Asia & 0.4 & 0.8 & 1.2 \\
\hline Rest of Southeast Asia & 1.2 & 6.6 & 2.4 \\
\hline World & 11.0 & 75.0 & 64.0 \\
\hline
\end{tabular}

Notes: $\mathrm{A} 1 \mathrm{~B}$ is consistent with the A1B IMAGE scenario, which assumes a warming of $2.4^{\circ} \mathrm{C}$ by the $2050 \mathrm{~s}$ and $3.8^{\circ} \mathrm{C}$ by the 2090s; RAHM is from Rahmstorf (2007), where the sea level rises by 1.4 meters by 2100; RCP are the Representative Concentration Pathways; High is from Lowe and Gregory (2010), where the sea level rise is projected to be 2 meters by 2100 .

While cumulative migration in high SLR scenarios is always higher, this research takes the average values for the 2070s, 2080s and 2090s. In some high SLR cases, e.g. the People's Republic of

China, much migration has already occurred in earlier decades, so the additional migration in these three decades is lower in the high SLR scenarios than the A1B scenario.

Sources: Jonathan Pycroft, Jan Abrell, and Juan-Carlos Ciscar. 2015. "The Global Impacts of Extreme Sea Level Rise: A Comprehensive Economic Assessment." Environmental Resource Economics. doi: 10.1007/s10640-014-9866-9

8 FUND3.6 is an integrated assessment model originally developed by Tol (1997) which aims to advise policy makers on the characteristics of an optimal policy rather than to evaluate the economic and climate consequences of proposed policies (ADB 2013). PAGE09 is a new version of the PAGE integrated assessment model that values the impacts of climate change and the costs of policies to abate and adapt to it (Hope 2010). 


\section{Tourism}

Based on IPCC (2014), coastal tourism has been the largest component of the global tourism industry. Burke et al. (2011) discovered that more than 100 countries benefit from the recreational value provided by their coral reefs, which contributed $\$ 11.5$ billion to global tourism. The tourism industry is one of the world's largest industries, accounting for about $9 \%$ of global GDP and provides jobs to people worldwide. The sector is particularly important for some of the world's poorest countries, especially some of the small island states (Nicholls 2014).

Tourism is a low-lying fruit that any coastal community can take advantage of to promote domestic jobs. Thus, tourism is an important economic growth driver. In fact, the World Tourism Organization (UNWTO 2016) announced that 2015 international tourist arrivals grew by 4.4\%, about 1.2 billion arrivals, almost reaching the projection of 1.6 billion by 2020 . Many developing countries depend on tourism as a main driver of economic growth. However, climate change poses many challenges to the development of tourism and to the gains that tourism has already garnered in many coastal scenic cities and communities.

An appropriate example of the impact of SLR on tourism is the Maldives. Some researchers find that the country is very vulnerable to SLR and that it faces the very real possibility of the majority of its land area being inundated by $2100 .{ }^{9}$ According to Climate Hot Map, the white sand beaches and extensive coral reefs of its 1,190 islands draw more than 600,000 tourists annually. The Maldives relies on its marine life and beaches to sustain a tourism industry that contributes over $30 \%$ of total GDP.

Moreover, Pfeffer, Harper, and O'Neel (2008) estimate that the sea level could rise 0.8-2 m, depending on the amount of carbon emissions released. Their study revealed that the Maldives will experience a rise in sea level of $0.5 \mathrm{~m}$ by around 2100 and would lose $77 \%$ of its land area by the end of the century (Tol 2007). If the sea level were to rise by $1 \mathrm{~m}$ and no further coastal protection mechanism is instituted, the country would be nearly completely inundated by about 2085 (Anthoff, Nicholls, and Tol 2010). This obviously paints a stark future for the Maldives.

There is a lingering uncertainty in the tourism sector amid the anticipated threats of climate change, particularly the impact of SLR. While there is a large amount of literature on climate impacts, there is uncertainty surrounding tourist behavior and it is difficult to draw overarching conclusions due to lack of consistency and, often, conflicting information (IPCC 2013). However, these issues clearly point to the obvious urgency to prepare and adjust to the impacts of SLR on global tourism.

\section{SEA LEVEL RISE ADAPTATION STRATEGIES}

With the urgent need to address extreme weather and climate change-related events such as SLR, adaption strategies to manage the various risks are very crucial to how different countries that are vulnerable to these specific risks connect and become ready and resilient to the economic impacts such events bring.

Dronkers et al. (1990) outline several options to adapt for SLR and divide these into three categories: retreat, accommodation, and protection.

9 See Tol (2007); United Nations Office for the Coordination of Humanitarian Affairs (2007); Pfeffer, Harper, and O’Neel. (2008); Anthoff, Nicholls, and Tol (2010). 


\section{A. Retreat}

Retreat involves no effort to protect the land from the sea or refers to the planned movement of the population from hazard-prone sections of the coast (Alexander, Ryan, and Measham 2012), and, in extreme cases, the entire area may be totally abandoned. Researchers often emphasize how people in degraded or disaster-prone areas incorporate risk into their livelihoods through individual and community coping mechanisms. In this case, climate migration is used as a coping strategy and is a frequent response to both economic and environmental hardship (Raleigh, Jordan, and Salehyan 2008).

Generally, climate migration is presented as one of the most dramatic consequences of global warming. However, empirical research shows that migration can be a strategy if the affected population is given the means to do so in order to adapt to the degradation of their immediate environment (Gemenne 2010). Results by Diaz (2016) present economies with significant adaptation costs from migration due to SLR, and median spending is projected to be about $16 \%$ of 2050 GDP. Nauru has the highest adaptation cost at $40 \%$, while Tonga has the lowest at $2 \%$. It is also fitting to note that the Maldives (31\%); Hong Kong, China (29\%); and Tuvalu (22\%) have considerably huge costs compared to other developing Asian economies included.

In general, Dronkers et al. (1990) describe the different implications for the "retreat" strategy. This specific strategy will have obvious environmental impacts through ecosystems migrating landward as sea levels rise and thus potentially remaining largely intact, although the total area of wetlands would decline. Economic implications include that coastal landowners and communities would suffer from loss of property, resettlement costs, and the costs of rebuilding infrastructure. Resettlement could create major problems and is by and large difficult societally as it could lead, among others, to language barriers, racial and religious discrimination, and difficulties obtaining employment. Even when they feel welcome, the disruption of families, friendships, and traditions can be stressful.

\section{B. Accommodation}

Accommodation refers to the continued use of land at risk with no attempts to prevent the land from being flooded. In this strategy, the impacts to humans are minimized by adjusting the use of the coastal zones via flood-resilience measures (Nicholls 2011). The community, in order to adapt, will build emergency flood shelters, elevate buildings on piles, convert agriculture to fish farming, or grow floodor salt-tolerant crops (Knecht 1975). Other additional strategies are early warning and evacuation systems, improved drainage systems, and hazard insurance points under the accommodation strategy (Sterr, Klein, and Reese 2003).

There have been listed economic benefits to inundation and flooding under the accommodation strategy as it provides opportunities for land to be used for new purposes. Dronkers et al. (1990) suggest changing property values, increasing damage from storms, and costs for modifying infrastructure as among some of the economic impacts under accommodation.

\section{Protection}

Protection strategies normally refer to construction of dikes and sea walls. Hillen et al. (2010) give a reference cost of $\$ 6.02$ million per kilometer of coastline per vertical meter of protection. Diaz (2016) posts the results of the protection strategy, and among the developing Asian economies in the estimates, Tonga (65\%), Viet Nam (52\%), Sri Lanka (48\%), the PRC (37\%), Bangladesh (33\%), India (31\%), and 
Singapore (30\%) have the highest protection costs..$^{10}$ Protection from SLR can be cost-effective for richer countries vulnerable to SLR rather than poorer countries threatened by rising sea levels.

Again, Dronkers et al. (1990) are of the view that, under the protection option, a much larger proportion of these ecosystems would be lost; hence, protective structures should be designed to avoid adverse environmental impacts. On the economic impact of climate change, countries and communities would face the costs for the necessary structures that would protect economic development but could adversely affect economic interests that depend on recreation and fisheries. The estimated total cost of defenses would amount to about $\$ 500$ billion over the next 10 years (which only includes the marginal or added costs and is not discounted). Thus, the overall protection costs will be considerably higher (Dronkers et al. 1990). Therefore, decisions should be based on both long-term and short-term costs and benefits to ensure sustainable coastal development.

Moreover, the degradation of environment could disrupt family life and create social instability under the protection scenario and community participation in the decision-making process is the best way to ensure that these implications are recognized, regardless of the response eventually chosen (Dronkers, et al 1990). Again, the protection efforts may need regional and global cooperation to maximize their impact.

More importantly, it is crucial to distinguish and identify the various types of costs associated with SLR. Typically, SLR costs are either adaptation cost, which is the cost of protecting the coastal regions or the cost of moving people to higher regions, and the economic costs brought about by the flooding or inundation of land. Diaz (2016) segregated the different SLR costs into either protection, retreat, or flood costs, covering what are typically the types of SLR costs using new open-source optimization model, Coastal Impact and Adaptation Model (CIAM). The CIAM assesses coastal impacts by disaggregating the least-cost adaptation decisions and determines an efficient strategy for adaptation at the local level. Thus, the advantage is that it not only produces aggregate or global cost levels but also describes the impacts at a local level, where retreat is often defined as a more costefficient adaptation strategy than merely protection.

Table 3 outlines the national adaptation cost estimates of selected countries in developing Asia and the Pacific for the least-cost strategy in RCP8.5. Note that the columns from left to right describe the net present value of SLR impacts from 2010 to 2100 and the annual cost in 2050 as a percentage of national GDP, first as total cost and then decomposed into protection cost, retreat cost, expected flood cost, and the residual cost of inundation and wetland loss. ${ }^{11}$ Many small Pacific countries are included in the top 15 national adaptation cost estimates for SLR. The PRC, Indonesia,

10 Diaz (2016) also estimated total protection costs (as percentage of 2050 GDP) for the following economies: Bangladesh, 33\%; Cambodia, 0\%; PRC, 37\%; Fiji, 0\%; Georgia, 0\%; Hong Kong, China, 0\%; India, 31\%; Indonesia, 8\%; Japan, 19\%; Kiribati, 0\%; Malaysia, 12\%; Maldives, 5\%; Marshall Islands, 0\%; Federated States of Micronesia, 2\%; Myanmar, 2\%; Nauru, 0\%; Pakistan, 2\%; Palau, 0\%; Papua New Guinea, 0\%; Philippines, 7\%; Samoa, 0\%; Singapore, 30\%; Solomon Islands, 0\%; Sri Lanka, 48\%; Thailand, 31\%; Timor-Leste, 0\%; Tonga, 65\%; Tuvalu, 20\%; Vanuatu, 0\%; and Viet Nam, 52\%.

11 Protection construction costs are assumed to be linear to coastline length and quadratic to sea wall height, reflecting the increasing need for a structural foundation. There is also an annual maintenance cost and an opportunity cost to the occupied land. Gradual retreat incurs adaptation costs associated with redeveloping and relocating the affected people and infrastructure further inland. The expected cost of flooding is computed as the integral overall sea level extremes that exceed the current adaptation level. The incremental inundation of unprotected coastal land causes damage based on the extent of national land endowment lost and assumed to correspond in value to interior land. Wetland loss is an increasing function in the annual rate of SLR; permanent loss occurs when the rate exceeds a critical threshold for vertical accretion or if protection is chosen, as this physically prevents the natural migration of inhabitants (Diaz 2016). 
Malaysia, and India belong to the top 15 countries that have high national adaptation cost estimates based on net present value between 2010 and 2100.

\section{Table 3: Sea Level Rise Impact Estimates on Selected Countries in Developing Asia and the Pacific}

\begin{tabular}{l|c|c|c|c|c|c}
\hline Country & $\begin{array}{c}\text { NPV } \\
\text { (\$ billion) }\end{array}$ & $\begin{array}{c}2050 \text { Total } \\
(\% \text { of GDP) }\end{array}$ & $\begin{array}{c}\text { Protection } \\
(\% \text { of total) }\end{array}$ & $\begin{array}{c}\text { Retreat } \\
(\% \text { of total) }\end{array}$ & $\begin{array}{c}\text { Flood } \\
\text { (\% of total) }\end{array}$ & $\begin{array}{c}\text { Residual } \\
(\% \text { of total) }\end{array}$ \\
\hline Marshall Islands & 1.2 & 7.6 & 0.0 & 17.0 & 0.0 & 83.0 \\
\hline Maldives & 9.8 & 7.5 & 50.0 & 31.0 & 0.0 & 64.0 \\
\hline Tuvalu & 0.1 & 4.6 & 0.0 & 18.0 & 0.0 & 82.0 \\
\hline Kiribati & 0.5 & 4.1 & 0.0 & 20.0 & 0.0 & 80.0 \\
\hline Tonga & 0.9 & 2.5 & 65.0 & 2.0 & 0.0 & 32.0 \\
\hline Palau & 0.3 & 1.9 & 0.0 & 15.0 & 0.1 & 85.0 \\
\hline $\begin{array}{l}\text { Federated States of } \\
\text { Micronesia }\end{array}$ & 0.6 & 1.8 & 2.0 & 20.0 & 0.1 & 77.0 \\
\hline Nauru & 0.1 & 1.7 & 0.0 & 40.0 & 0.0 & 60.0 \\
\hline Median Country & 1.1 & 0.1 & 0.0 & 16.0 & 0.0 & 79.0 \\
\hline
\end{tabular}

GDP = gross domestic product, NPV = net present value.

Source: Diaz, Delavane B. 2016. "Estimating Global Damages from Sea Level Rise with the Coastal Impact and Adaptation Model (CIAM).” Climatic Change 137 (1): 143-56. doi:10.1007/s10584-016-1675-4

\section{POLICY RECOMMENDATIONS}

SLR and its impact on economic efficiency have been studied, and the probable impact on global GDP is known. The CIAM has also projected local or country-level impacts that are very important to consider moving on with adaptation strategies.

On the global scale, the Institute on Science for Global Policy (ISGP 2015), through its Climate Change Program put forward how to mitigate and/or adapt to the anticipated impact of changing climates (e.g., drought, SLR, severe storms, warming seas, and oceans). In particular, the ISGP recommends the following for issues concerning SLR. Recognizing the historic records and current projections indicating that the sea level can rise significantly within a short period of time (e.g., life cycle of a mortgage), it is of vital importance for the economic health and sustainability of the world that policy makers at all levels develop long-term anticipatory plans that

(i) create metrics-driven benchmarks for the implementation of policy actions;

(ii) identify strategies for addressing the overlapping issues of health, freshwater, food, shelter, infrastructure, and safety; and

(iii) consider the potential relocation and/or restructuring of affected communities. Policies need to be developed through extensive community education and engagement, and need to consider social, environmental, and economic issues related to societal inequities and vulnerable communities.

Dronkers et al. (1990) put forward three aspects of policy making regarding SLR: (i) national coastal planning; (ii) international cooperation; and (iii) research, data, and information. In the area of localized coastal planning, coastal nations are encouraged to implement comprehensive coastal zone management plans. To increase the likelihood of success against SLR, coastal areas at risk should be identified and known clearly. More importantly, countries should ensure that coastal development does not increase vulnerability to SLR. The different aspects required to help coastal development to 
be environmentally aligned to coastal protection plans should be secured. Moreover, emergency preparedness, coastal response mechanisms, and disaster relief schemes should be reviewed and further strengthened.

In international cooperation, a continuing effort to put in the forefront the effects and potential impact of SLR needs to be maintained. Technical assistance and capacity-building measures should be implemented to help better prepare vulnerable nations. Furthermore, international organizations should continuously support local efforts to contain population growth in coastal areas. Finally, research, data, and information dissemination should continuously be made crucial in the campaign to help vulnerable countries and other stakeholders protect themselves from the various impacts of SLR. SLR research and studies should be strengthened and maintained. The network of global ocean observatories should be continuously developed and seriously implemented. Data and information on sea level change and various adaptive options should be made widely available.

The application at local levels where SLR impacts so far are being felt by communities is important and crucial to the success of these recommendations. Note that the "localization" of education campaign and the relevance and accuracy of data to educate the local communities will play a huge role in making the SLR reality a personal responsibility of each person eventually affected by climate change through SLR.

\section{CONCLUSIONS}

This survey of SLR and its economic impacts provides a clear window to the effects of SLR on future economic activities, not just globally but also particularly on some developing Asian countries. The global perspective of some of the models considered here provide insight into the possible losses brought about by the increasing sea level. By 2100, economic losses may account for as much as $9.3 \%$ of global GDP and, as discussed, may vary by country.

Developing Asian countries that have been widely studied were included to provide a local context for the discussions. Specifically, the examples of Kiribati and Singapore have been highlighted to bring to the fore the immediate impact of SLR as it is now. A locally focused adaptation strategy is very important as every single member of the population directly affected by SLR will have to take responsibility in one way or another. The education of and the acceptance by the concerned local community will be crucial in the successful implementation of SLR adaptation strategies, notwithstanding parallel mitigation efforts by everyone. The local authorities take on the role of emphasizing the need for long-term coastal adaptation strategies as central to addressing SLR.

The effects of SLR are undeniable. Low-lying countries are now experiencing what the scientists and other scholars have widely studied and researched. Thus, international efforts to put the impacts and potential effects of SLR in the forefront are important and need to be continued. Technical assistance and capacity-building measures should be carried out to help prepare the most vulnerable economies for catastrophic impacts. Worldwide efforts, through international organizations, must continue to support the localization of efforts to alleviate the impacts of climate change through SLR. Research and consequently the data that it will further produce should be made available and information dissemination intensified for vulnerable countries and other important stakeholders to be protected from the impacts of SLR. 


\section{REFERENCES}

Alexander, Kim S., Anthony Ryan, and Thomas G. Measham. 2012. "Managed Retreat of Coastal Communities: Understanding Responses to Projected Sea Level Rise." Journal of Environmental Planning and Management 55 (4): 409-33.

Anthoff, David, Robert J. Nicholls, and Richard S. J. Tol. 2010. "The Economic Impact of Substantial Sea Level Rise. Mitigation and Adaptation Strategies for Global Change.”15 (4): 321-35.

Asian Development Bank (ADB). 2013. The Economics of Climate Change in the Pacific. Manila.

Burke, Lauretta M., Kathleen Reytar, Mark Spalding, and Allison Perry. 2011. Reefs at Risk Revisited. Washington, DC: World Resources Institute.

Burke, Marshall, Solomon M. Hsiang, and Edward Miguel. 2015. "Global Non-linear Effect of Temperature on Economic Production.” Nature 527 (7577): 235-39.

Cazenave, Anny, and William Llovel. 2010. "Contemporary Sea Level Rise." Annual Review of Marine Science 2:145-173. doi:10. 1146/annurev-marine-120308-081105

Church, John A., and Neil J. White. 2011. "Sea Level Rise from the Late 19th to the Early 21st Century." Surveys in Geophysics 32 (4): 585-602. doi:10.1007/s10712-011-9119-1

Ciscar, Juan-Carlos, Laszlo Szabo, Denise van Regemorter, and Antonio Soria. 2012. "The Integration of PESETA Sectoral Economic Impacts into GEM-E3 Europe: Methodology and Results." Climatic Change 112 (1): 127-42. doi:10.1007/s10584-011-0343-y

Climate Hot Map. Sea-Level Rise in the Republic of Maldives. http://www.climatehotmap.org/globalwarming-locations/republic-of-maldives.html (accessed 21 November 2016).

Commonwealth Scientific and Industrial Research Organisation. 2015. www.cmar.csiro.au/sealevel/ sl_data_cmar.html

Decloitre, Shobhna. 2010. "The Rising Sea, the Changing Tides in Kiribati. Pacific Conference on the Human Face of the Global Economic Crisis." New York, NY: United Nations Development Programme.

Dell, Melissa, Benjamin F. Jones, and Benjamin A. Olken. 2012. "Temperature Shocks and Economic Growth: Evidence from the Last Half Century." American Economic Journal: Macroeconomics 4(3): 66-95.

Diaz, Delavane B. 2016. "Estimating Global Damages from Sea Level Rise with the Coastal Impact and Adaptation Model (CIAM).” Climatic Change 137 (1): 143-56. doi:10.1007/s10584-016-1675-4

Dronkers, Jaap, John Gilbert, Lisa Butler, John J. Carey, Jon Campbell, E. James, C. McKenzie, Robert Misdorp, Niall Quinn, K. L. Ries, Peter C. Schroder, Julian Spradley, James Titus, Limberios Vallianos, and Jane von Dadelszen. 1990. "Strategies for Adaptation to Sea Level Rise." Report of the IPCC Coastal Zone Management Subgroup: Intergovernmental Panel on Climate Change, Geneva. 
Environmental Protection Agency. Climate Change Indicators in the United States. https://www.epa.gov/climate-indicators/climate-change-indicators-sea-level

Ericson, Jason P., Charles J. Vorosmarty, S. Lawrence Dingman, Larry G. Ward, and Michel Meybeck. 2006. "Effective Sea Level Rise and Deltas: Causes of Change and Human Dimension Implications." Global Planet Change 50 (1): 63-82.

Findley, Sally E. 1994. "Does Drought Increase Migration? A Study of Migration from Rural Mali during the 1983-1985 Droughts." International Migration Review 28 (3): 539-53.

Food and Agriculture Organization of the United Nation. 2014. The State of World Fisheries and Aquaculture. Rome.

Gemenne, Francois. 2010. "Migration, a Possible Adaptation Strategy?" Institute for Sustainable Development and International Relations (IDDRI) No. 03/10.

Hallegatte, Stephane. 2012. "A Framework to Investigate the Economic Growth Impact of Sea Level Rise." Environmental Research Letters 7 (1): 1-7. IOP Publishing, Sustainable Development Network. World Bank. doi:10.1088/1748-9326/7/1/015604

Hauer, F. Richard, Harvey Locke, Victoria Drietz, Mark Hebblewhite, Winsor H. Lowe, Clint C. Muhlfeld, Cara R. Nelson, Michael F. Proctor, and Stewart B. Rood. 2016. "Gravel-Bed River Floodplains Are the Ecological Nexus of Glaciated Mountain Landscapes." Science Advances 2 (6): e1600026. doi:10.1126/sciadv.1600026

Hillen, Marten M., Sebastiaan N. Jonkman, Wim Kanning, Matthijs Kok, Marli Geldenhuys, and Marcel Stive. 2010. "Coastal Defence Cost Estimates: Case Study of the Netherlands, New Orleans and Viet Nam." Delft University of Technology, Department Hydraulic Engineering.

Hinkel, Jochen, Daniel Lincke, Athanasios T. Vafeidis, Mahé Perrette, Robert James Nicholls, Richard S. J. Tol, Ben Marzeion, Xavier Fettweis, Cezar lonescu, and Anders Levermann. 2014. "Coastal Flood Damage and Adaptation Costs under 21st Century Sea Level Rise." Proceedings of the National Academy of Sciences of the United States of America 111 (9): 3292-97.

Hope, Chris. 2010. The PAGE09 Model: Estimating Climate Impacts and the Social Cost of $\mathrm{CO}_{2}$. Washington, DC: Environmental Protection Agency.

Institute on Science for Global Policy (ISGP). 2015. Sea Level Rise: What's Our Next Move? Conference organized by the ISGP in partnership with the Institute for Strategic Policy Solutions at St. Petersburg College and a local committee of concerned volunteers, the St. Petersburg/Pinellas County Working Group, and convened on the St. Petersburg College Seminole Campus, 2-3 October. http://scienceforglobalpolicy.org/wp-content/uploads/56e30928039ff-ISGP\%20Sea $\% 20$ Level\%20Rise.pdf

Intergovernmental Panel on Climate Change (IPCC). 2001. Climate Change 2001: The Scientific Basis. Contribution of Working Group I to the Third Assessment Report of the Intergovernmental Panel on Climate Change, edited by John T. Houghton, Yihui Ding, David J. Griggs, Maria Noguer, Paul J. van der Linden, Xiaosu Dai, Kathy Maskell, and Cathy A. Johnson. Cambridge, UK and New York, NY: Cambridge University Press. 
2007. Climate Change 2007: Impacts, Adaptation and Vulnerability. Working Group II Contribution to the Fourth Assessment Report of the Intergovernmental Panel on Climate Change. Geneva.

2013. Climate Change 2013: The Physical Science Basis. Working Group I Contribution to the Fifth Assessment Report of the Intergovernmental Panel on Climate Change. Geneva.

2014. Climate Change 2014: Impacts, Adaptation, and Vulnerability. Part A: Global and Sectoral Aspects. Contribution of Working Group II to the Fifth Assessment Report of the Intergovernmental Panel on Climate Change. Cambridge, UK and New York, NY: Cambridge University Press.

Knecht, Ronald W. 1975. “Coastal Zone Management.” Science 187 (4179): 789-90.

Kopp, Robert E., Radley M. Horton, Christopher M. Little, Jerry X. Mitrovica, Michael Oppenheimer, D. J. Rasmussen, Benjamin H. Strauss, and Claudia Tebaldi. 2014. "Probabilistic 21st and 22nd Century Sea Level Projections at a Global Network of Tide-Gauges Sites.” Earth's Future 2 (8): 383-406. doi:10.1002/2014EF000239

Levitus, Sydney, John I. Antonov, and Timothy P. Boyer. 2005. "Warming of the World Ocean, 19552003.” Geophysical Research Letters 32 (2): L02604. doi:10.1029/2004GL021592

Levitus, Sydney, John I. Antonov, Timothy P. Boyer, Ricardo A. Locarnini, Hernan E. Garcia, and Alexey V. Mishonov. 2009. "Global Ocean Heat Content 1955-2008 in Light of Recently Revealed Instrumentation Problems." Geophysical Research Letters 36 (L07608). doi:10.1029/2008GL037155

Levitus, Sydney, John I. Antonov, Julia Wang, Thomas L. Delworth, Keith W. Dixon, and Anthony J. Broccoli. 2001. “Anthropogenic Warming of Earth's Climate System.” Science 292 (5515): 26770. doi:10.1126/science.1058154

Lombard, Alix, Anny Cazenave, Kien DoMinh, Cecile Cabanes, and R. Steven Nerem. 2005. "Thermosteric Sea Level Rise for the Past 50 Years; Comparison with Tide Gauges and Inference on Water Mass Contribution." Global and Planetary Change 48 (4): 303-12.

Lowe, Jason A., and Jonathan M. Gregory. 2010. "A Sea of Uncertainty." Nature Reports Climate Change 4: 42-43.

Maxwell, Daniel. 1999. “Programs in Chronically Vulnerable Areas.” Disasters 23 (4): 373-84.

Mengel, Matthias, Anders Levermann, Katja Frieler, Alexander Robinson, Ben Marzeion, and Ricarda Winkelmann. 2016. "Future Sea Level Rise Constrained by Observations and Long-term Commitment." Proceedings of the National Academy of Sciences of the United States of America 113 (10): 2597-602.

Meze-Hausken, Elisabeth. 2000. "Migration Caused by Climate Change: How Vulnerable Are People in Dryland Areas?" Mitigation and Adaptation Strategies 5 (4): 379-406. 
Mula, Rosana. 1999. "Coping with Mother Nature: Household Livelihood Security and Coping Strategies in a Situation of a Continuing Disaster in Tarlac, Philippines." PhD thesis, Wageningen.

National Oceanic and Atmospheric Administration. 2015. Laboratory for Satellite Altimetry: Sea Level Rise. https://www.star.nesdis.noaa.gov/sod/lsa/SeaLevelRise/

2016. Tides and Currents. https://tidesandcurrents.noaa.gov/sltrends/globalregional.htm

Navaratnarajah, Romesh. 2015. "Climate Change Could Force 745,000 Singaporeans Underwater." PropertyGuru. 9 November. http://www.propertyguru.com.sg/property-managementnews/2015/11/110967/climate-change-could-force-745000-singaporeans-underwater

The New York Times. 2016. "A Remote Pacific Nation, Threatened by Rising Seas.” 3 July.

Ng, Wei-Shiuen, and Robert Mendelsohn. 2005. "The Impact of Sea Level Rise on Singapore." Environmental and Development Economics 10 ( 2): 201-15.

Nicholls, Mark. 2014. "Climate Change: Implications for Tourism. Key Findings from the Intergovernmental Panel on Climate Change Fifth Assessment Report." University of Cambridge. https://europeanclimate.org/wp-content/uploads/2014/06/Tourism_Briefing _Web_EN.pdf

Nicholls, Robert J. 2011. “Planning for the Impacts of Sea Level Rise.” Oceanography 24 (2): 144-57.

Perch-Nielsen, Sabine L. 2004. "Understanding the Effect of Climate Change on Human Migration: The Contribution of Mathematical and Conceptual Models." Diploma thesis. Swiss Federal Institute of Technology, Zurich.

Pfeffer, W. Tad, J. T. Harper, and Shad O’Neel. 2008. "Kinematic Constraints on Glacier Contributions to 21st-Century Sea Level Rise.” Science 321 (5894): 1340-43.

Pycroft, Jonathan, Jan Abrell, and Juan-Carlos Ciscar. 2015. "The Global Impacts of Extreme Sea Level Rise: A Comprehensive Economic Assessment." Environmental Resource Economics. doi:10.1007/s10640-014-9866-9

Rahmstorf, Stefan. 2007. "A Semi-Empirical Approach to Projecting Future Sea Level Rise." Science 315 (5810): 368-70.

Raleigh, Clionadh, Lisa Jordan, and Idean Salehyan. 2008. "Assessing the Impact of Climate Change on Migration and Conflict." Paper presented at Social Dimensions of Climate Change, Social Development Department, World Bank, Washington, DC, 5-6 March.

Schaeffer, Michiel, Bill Hare, Stefan Rahmstorf, and Martin Vermeer. 2012. "Long-Term Sea Level Rise Implied by $1.5^{\circ} \mathrm{C}$ and $2^{\circ} \mathrm{C}$ Warming Levels." Nature Climate Change 2: 867-70. 
Sterr, Horst, Richard Klein, and Stefan Reese. 2003. "Climate Change and Coastal Zones: An Overview of the State-of-the-Art on Regional and Local Vulnerability Assessment." In Climate Change in the Mediterranean: Socio-Economic Perspectives of Impacts, Vulnerability and Adaptation, edited by Carlo Giupponi and Mordechai Shechter. Cheltenham, UK: Edward Elgar. pp. 245-78.

Strassburg, Matthew, Benjamin Hamlington, Robert Leben, Parluhutan Manurung, Jonson L. Gaol, Bisman Nababan, Stefano Vignudelli, and Kwon Kim. 2015. "Sea Level Trends in Southeast Asian Seas." Climate of the Past 11 (5): 743-50.

Tol, Richard S. J. 1997. "On the Optimal Control of Carbon Dioxide Emissions: An Application of FUND.” Environmental Modeling \& Assessment 2 (3): 151-63.

- 2007. "The Double Trade-Off between Adaptation and Mitigation for Sea Level Rise: An Application of FUND." Mitigation and Adaptation Strategies for Global Change 12 (5): 741-53.

United Nations Development Programme, United Nations Environment Programme, World Bank, and World Resources Institute. 2000. World Resources 2000-2001, People and Ecosystems: The Fraying Web of Life, September. http://www.wri.org/publication/world-resources-2000-2001

United Nations Office for the Coordination of Humanitarian Affairs. 2007. Maldives: Coastal Flooding. OCHA Situation Report No. 3. New York, NY. http://reliefweb.int/node/233884

Vermeer, Martin, and Stefan Rahmstorf. 2009. "Global Sea Level Linked to Global Temperature." Proceedings of the National Academy of Sciences of the United States of America 106: 21527-32.

World Bank. 2013. Acting on Climate Change and Disaster Risk for the Pacific http://wwwwds.worldbank.org/external/default/WDSContentServer/WDSP/IB/2013/11/20/000442464_ 20131120105129/Rendered/PDF/808690Revised000Box379874B00PUBLIC0.pdf

World Tourism Organization (UNWTO). 2016. International Tourist Arrivals Up 4\% Reach Record 1.2 Billion in 2015. Press release, 8 January. http://media.unwto.org/press-release/2016-0118/international-tourist-arrivals-4-reach-record-12-billion-2015 (accessed 20 November 2016). 


\section{Impacts of Sea Level Rise on Economic Growth in Developing Asia}

This paper examines the impact of global sea level rise (SLR) on the economic growth, migration, and tourism from various empirical studies and consolidates several sea level projections by 2100 under different scenarios. The paper points out that the regions or countries most vulnerable to SLR include atoll countries and small islands states like Kiribati and Singapore. In addition, it tackles several adaptation cost estimates for selected countries in developing Asia and summarizes adaptive strategies and mitigation as a response to SLR which include retreat, accommodation, and protection. The paper also presents policy recommendations for developing Asia to cope with increasing sea levels.

\section{About the Asian Development Bank}

ADB's vision is an Asia and Pacific region free of poverty. Its mission is to help its developing member countries reduce poverty and improve the quality of life of their people. Despite the region's many successes, it remains home to a large share of the world's poor. ADB is committed to reducing poverty through inclusive economic growth, environmentally sustainable growth, and regional integration.

Based in Manila, ADB is owned by 67 members, including 48 from the region. Its main instruments for helping its developing member countries are policy dialogue, loans, equity investments, guarantees, grants, and technical assistance. 